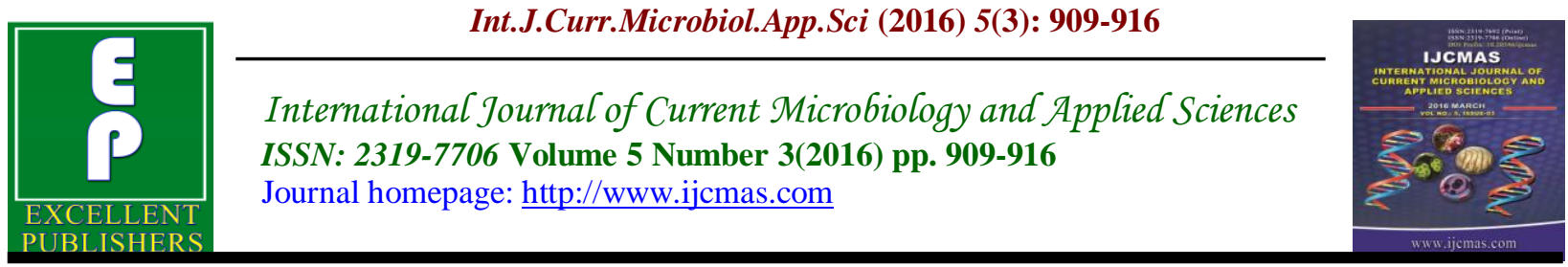

Original Research Article

http://dx.doi.org/10.20546/ijcmas.2016.503.105

\title{
Thermal Optimization of $\alpha$-amylase Production in Brevibacillus sp
}

\author{
K.Suribabu $^{1} *$ and K.P.J Hemalatha ${ }^{2}$ \\ ${ }^{1}$ Department Microbiology and Research Centre, Dr. Lankapalli Bullayya \\ Post-graduate College, Visakhapatnam-530 013.A.P, India \\ ${ }^{2}$ Department Microbiology, Andhra University, Visakhapatnam-530 003.A.P, India \\ *Corresponding author
}

\section{A B S T R A C T}

\begin{abstract}
Keywords
Brevibacillus borostelensis R1; $\alpha$-amylase;

Media;

Temperature

Article Info

Accepted:

25 February 2016

Available Online:

10 March 2016

Thermostability is a desired characteristic of most of the industrial enzymes. The production of $\alpha$-amylases has been thoroughly investigated and observed that it was affected by a variety of physiochemical factors, such as the composition of the growth medium under various temperature parameters with constant $\mathrm{pH}$ 7.0. The enzyme production was assayed in submerged fermentation $(\mathrm{SmF})$ condition. The optimum production of $\alpha$-amylase by $\mathrm{SmF}$ was observed at $4^{\circ} \mathrm{C}$ in Clarks and Lub Medium $(2551 \pm 1 \mathrm{U} / \mathrm{ml})$, Soybean Casein Digest Medium $(920 \pm 0.13 \mathrm{U} / \mathrm{ml})$ and Tryptone Glucose Beef Extract Medium ( $260 \mathrm{U} / \mathrm{ml})$. The optimum production of $\alpha$ amylase by $\mathrm{SmF}$ was observed at $25^{\circ} \mathrm{C}$ in Nutrient Broth $(270 \mathrm{U} / \mathrm{ml})$. The optimum production of $\alpha$-amylase by $\mathrm{SmF}$ was observed at $37^{\circ} \mathrm{C}$ in Pikovskaya's Medium $(3371 \pm 0.50 \mathrm{U} / \mathrm{ml})$, Tendler's Non-synthetic Medium (761 $\pm 0.50 \mathrm{U} / \mathrm{ml})$, Amylase Production Medium (580 U/ml) and Soluble Starch Beef Extract Medium (1930 $\mathrm{U} / \mathrm{ml}$ ). The optimum production of $\alpha$-amylase by $\mathrm{SmF}$ was observed at $50^{\circ} \mathrm{C}$ in Luria Bertain Broth $(240 \pm 0.12 \mathrm{U} / \mathrm{ml})$ and Yeast extract peptone Glycerol Glucose Medium (265 U/ml). Thermal variability of $\alpha$-amylase produced by Brevibacillus borostelensis $\mathrm{R} 1$ in various media may have a significant role in many applications like bakery industry, treatment of effluents from sago and rice industry, sewage water treatment, fodder production, laundry industry and textile industry.
\end{abstract}

\section{Introduction}

High temperatures damage bacteria by denaturing enzymes, transport carriers, and other proteins. Bacterial membranes are also disrupted by temperature extremes; the lipid bilayer simply melts, disintegrates and leaks. At very low temperatures, membranes solidify and enzymes do not work rapidly. The broad range of temperatures and the enzyme's high activity at both moderate and lower temperature make this enzyme highly attractive for both basic research studies and industrial processes. A modern trend among consumers is to use colder temperatures for laundry or dishwashing. The removal of starch from cloth and porcelain becomes more problematic at low temperatures; to overcome this problem, detergents with $\alpha$ amylases at low or moderate temperatures can be used (Van der Maarel, 2002). Thermostability is a desired characteristic of 
most of the industrial enzymes. Thermostable $\alpha$-amylases are reported from the mesophile Bacillus species Teodoro \& Martin, 2000; Burhan et al., 2003). Therefore, a high value is placed on extreme thermostability and thermoactivity of the enzymes. Many authors reported the $\alpha$ amylase production in psychrophilic bacteria (Feller et al., 1999; Michael et al., 2005; Siddiqui et al., 2006), mesophilic bacteria (Rajagopalan et al., 2008; Kuddus et al., 2012) and thermophilic bacteria (Mukherjee et al., 2009; Asoodeh et al., 2010; Abha Singh et al., 2012; Akcan et al., 2012; Sailas Benjamin et al., 2013).

\section{Materials and Methods}

\section{Collection of the Marine Water Samples}

Marine water samples were collected from coastal areas of Visakhapatnam across the Bay of Bengal, Rushikonda(R), Visakhapatnam, Andhra Pradesh, India. The water samples were collected from the above site in sterile BOD bottles (Borosil) and brought to the laboratory for study.

\section{Primary Screening of $\alpha$-amylase Producing Bacteria}

The collected marine water samples were diluted by serial dilution technique. The diluted samples of $10^{-4}$ to $10^{-6}(0.1 \mathrm{ml})$ were spreaded with L-shaped glass rod by spread plate technique on the starch agar plates. After incubation at $37^{\circ} \mathrm{C}$ for 24 hours, the plates were flooded with Lugol solution (1\% iodine in $2 \%$ potassium iodide $\mathrm{w} / \mathrm{v}$ ) (Amoozegar et al., 2003). The zone of hydrolysis measuring more than $11 \mathrm{~mm}$ were selected for further screening of amylase activity.

\section{Optimization of Temperature}

Hundred $\mathrm{ml}$ of the ten media: Nutrient Broth (NB), Luria Bertain Broth (LB), Clarks and
Lub Medium (CL), Pikovskaya's Medium (PK), Tendler's Non-synthetic Medium (TNS), Amylase Production Medium (APM), Soluble Starch Beef Extract Medium (SB), Soybean Casein Digest Medium (SCD), Yeast Extract peptone Dextrose Glucose Medium (YPDG) and Tryptone Glucose Beef Extract (TGB) Medium are procured from Himedia, India were taken in Erlenmeyer flasks. Two percent of pure culture of Brevibacillus borostelensis R1 isolated from coastal waters of Bay of Bengal, Visakhapatnam from pre-incubated pure strain was inoculated to each of Erlenmeyer flask. All the ten media were shaken gently and incubated at different $\left(4^{0} \mathrm{C}, 25^{\circ} \mathrm{C}, 37^{0} \mathrm{C}\right.$, $50^{\circ} \mathrm{C}$ and $60^{\circ} \mathrm{C}$ ) temperatures for 24 hours. After incubation, the sample was subjected for centrifugation (Remi) at 5,000 rpm for 15 minutes at room temperature. The supernatant was collected in sterile test tubes (Borosil) and the pellet was discarded.

\section{Assay of $\alpha$-amylase}

The starch substrate $[0.5 \mathrm{ml}$ of $0.5 \%$ in $0.1 \mathrm{M}$ phosphate buffer ( $\mathrm{pH}$ 6.8)] was mixed with $1 \%(0.2 \mathrm{ml}) \mathrm{NaCl}$ in a test tube and preincubated at $37^{\circ} \mathrm{C}$ for 10 minutes. The supernatant collected from the centrifugation of the production media was used as enzyme source, $0.5 \mathrm{ml}$ of this was added to the reaction mixture. The reaction was terminated by the addition of $1.0 \mathrm{ml}$ of 3,5 dinitrosalicylic acid reagent [1.0 gm DNS in $0.8 \% \mathrm{NaOH}, 60 \% \mathrm{Na} \mathrm{K}$ tartrate] after incubation at $37^{0} \mathrm{C}$ for 15 minutes. The contents were mixed well and kept in boiling water bath for 10 minutes. Then they were cooled and diluted with $10 \mathrm{ml}$ of distilled water. The color developed was read at $520 \mathrm{~nm}$ in colorimeter. One unit of enzyme activity is defined as the amount of enzyme that that releases one micromole of maltose per minute under the standard assay conditions. Estimation of $\alpha$-amylase activity 
was carried out according to the dinitro salicylic acid (DNS) method (Miller, 1959). All chemicals are procured from MERCK, Mumbai, India. All the above experiments were carried out in quadrant sets and standard deviation was calculated.

\section{Results and Discussion}

The potent $\alpha$-amylase producing Brevibacillus borostelensis R1 was isolated by using primary screening. The B.borostelensis R1 was identified by colony, morphological, biochemical and $16 \mathrm{~S}$ gene sequencing. The scanning electron micrograph of $B$. borostelensis R1 is shown in figure1.

The highest $\alpha$-amylase activity was observed in various media at different temperatures. At $4{ }^{\circ} \mathrm{C}$ the optimum amylase observed in $\mathrm{CL}$ $(2551 \pm 1 \mathrm{U} / \mathrm{ml}), \mathrm{SCD}(920 \pm 0.13 \mathrm{U} / \mathrm{ml})$ and TGB medium $(260 \mathrm{U} / \mathrm{ml})$; At $25^{\circ} \mathrm{C}$ the optimum amylase observed in NB (270 $\mathrm{U} / \mathrm{ml}$ ), at $37^{\circ} \mathrm{C}$ the optimum amylase observed in PK $(3371 \pm 0.50 \mathrm{U} / \mathrm{ml})$, TNS medium $(761 \pm 0.50 \mathrm{U} / \mathrm{ml})$, APM $(580$ $\mathrm{U} / \mathrm{ml})$ and $\mathrm{SB}$ medium $(1930 \mathrm{U} / \mathrm{ml})$. At $50^{\circ} \mathrm{C}$ the optimum amylase observed in LB medium $(240 \pm 0.12 \mathrm{U} / \mathrm{ml})$ and YPDG medium $(265 \mathrm{U} / \mathrm{ml})$ the results are shown in figures $2 \mathrm{a}-\mathrm{f}$ and $2 \mathrm{~g}-\mathrm{j}$.
The lowest amylase activity was observed in different media at different temperatures. At $4^{\circ} \mathrm{C}$ the lowest amylase activity was observed in NB $(80 \mathrm{U} / \mathrm{ml})$, LB medium (160U/ml), TNS medium (310U/ml), APM (200U/ml), SB medium (315U/ml). At $25^{\circ} \mathrm{C}$ the lowest amylase activity was observed in CL medium $(940 \mathrm{U} / \mathrm{ml})$ and TGB medium $(120 \mathrm{U} / \mathrm{ml})$, at $50^{\circ} \mathrm{C}$ the lowest amylase activity was observed in SCD medium $(110 \mathrm{U} / \mathrm{ml})$, at $60^{\circ} \mathrm{C}$ the lowest amylase activity was observed in $\mathrm{PK}$ medium $(1280 \pm 0.25 \mathrm{U} / \mathrm{ml})$, at $4^{\circ} \mathrm{C}$ and $25^{\circ} \mathrm{C}$ the lowest amylase activity was observed in YPDG medium (170U/ml). The range of amylase activity observed in different media at different temperatures is shown in table 1.

The amylase produced by Brevibacillus borostelensis $\mathrm{R} 1$ at various temperature conditions $\left(4^{\circ} \mathrm{C}, 25^{\circ} \mathrm{C}, 37^{\circ} \mathrm{C}, 50^{\circ} \mathrm{C}\right.$ and $\left.60^{\circ} \mathrm{C}\right)$ in ten different media was estimated. The outcome displayed the peak production of amylase occurred in psychrophilic condition when grown in media - CL, SCD and TGB; in mesophilic condition the peak production of amylase observed in NB, PK, TNS, APM and SB media and in thermophilic condition the highest production was observed in LB and YPDG media.

Figure.1 Scanning Electron Micrograph of Brevibacillus borostelensis R1

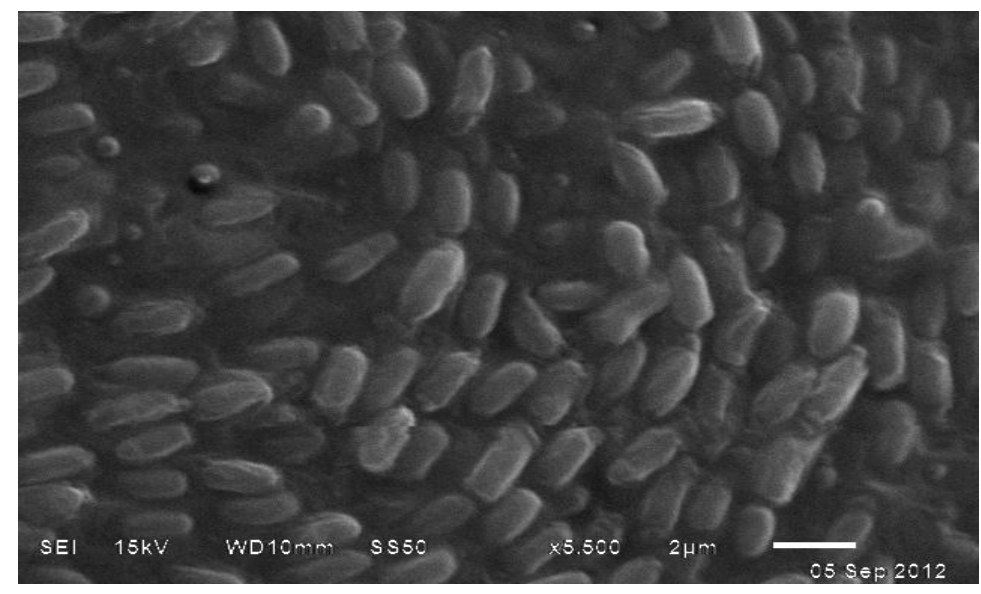


Figure.2 a-f Effect of Temperature on the Production of $\alpha$-amylase by Brevibacillus borstelensis R1 in Various Media: a, NB; b, LB Medium; c, CL Medium; d, PK Medium;e, TNS Medium and f, APM
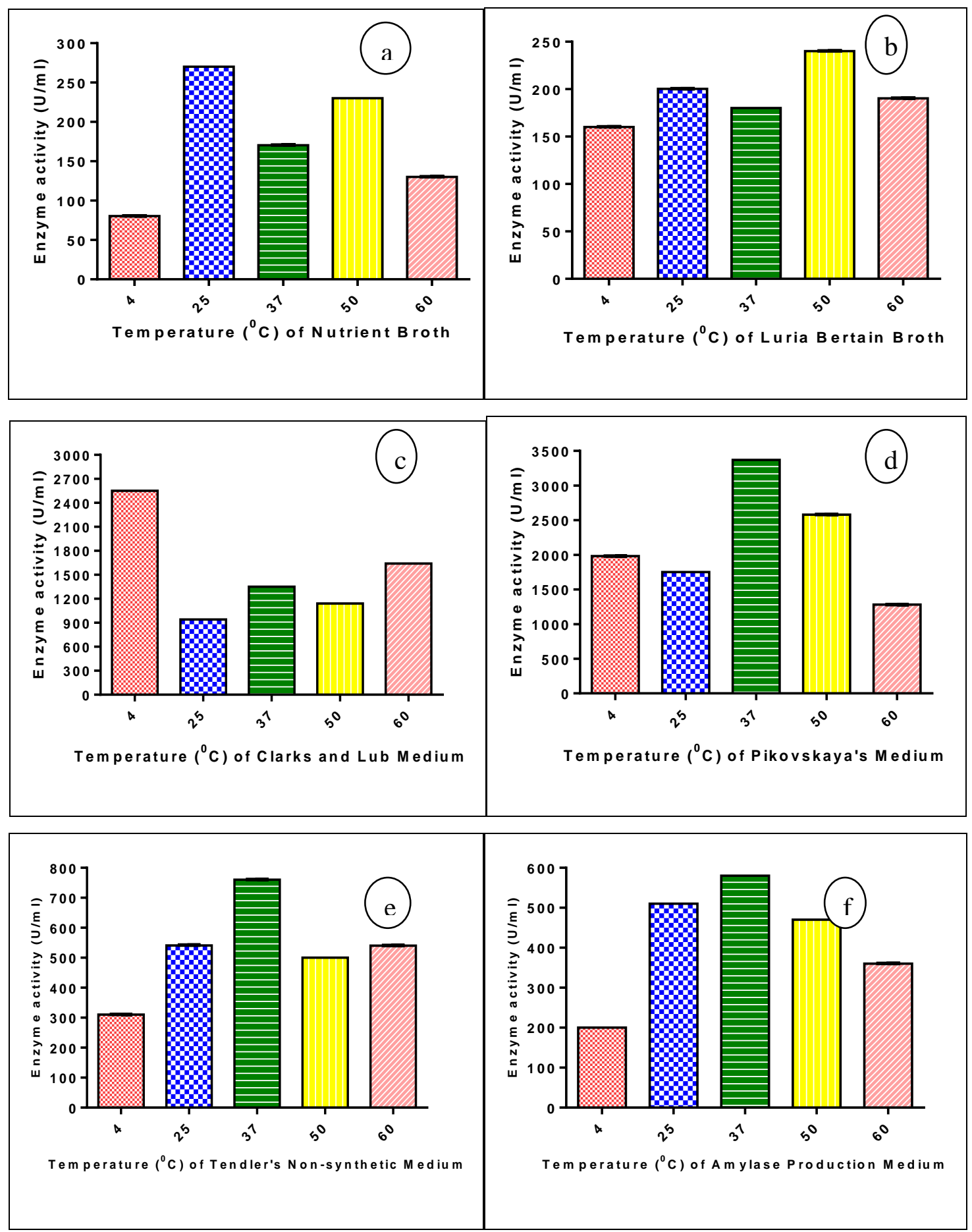
Figure.2 g-j Effect of Temperature on the Production of $\alpha$-amylase by Brevibacillus borstelensis R1 in Various Media: g, SB Medium; h, SCD Medium; i, YPDG Medium and j, TGB Medium
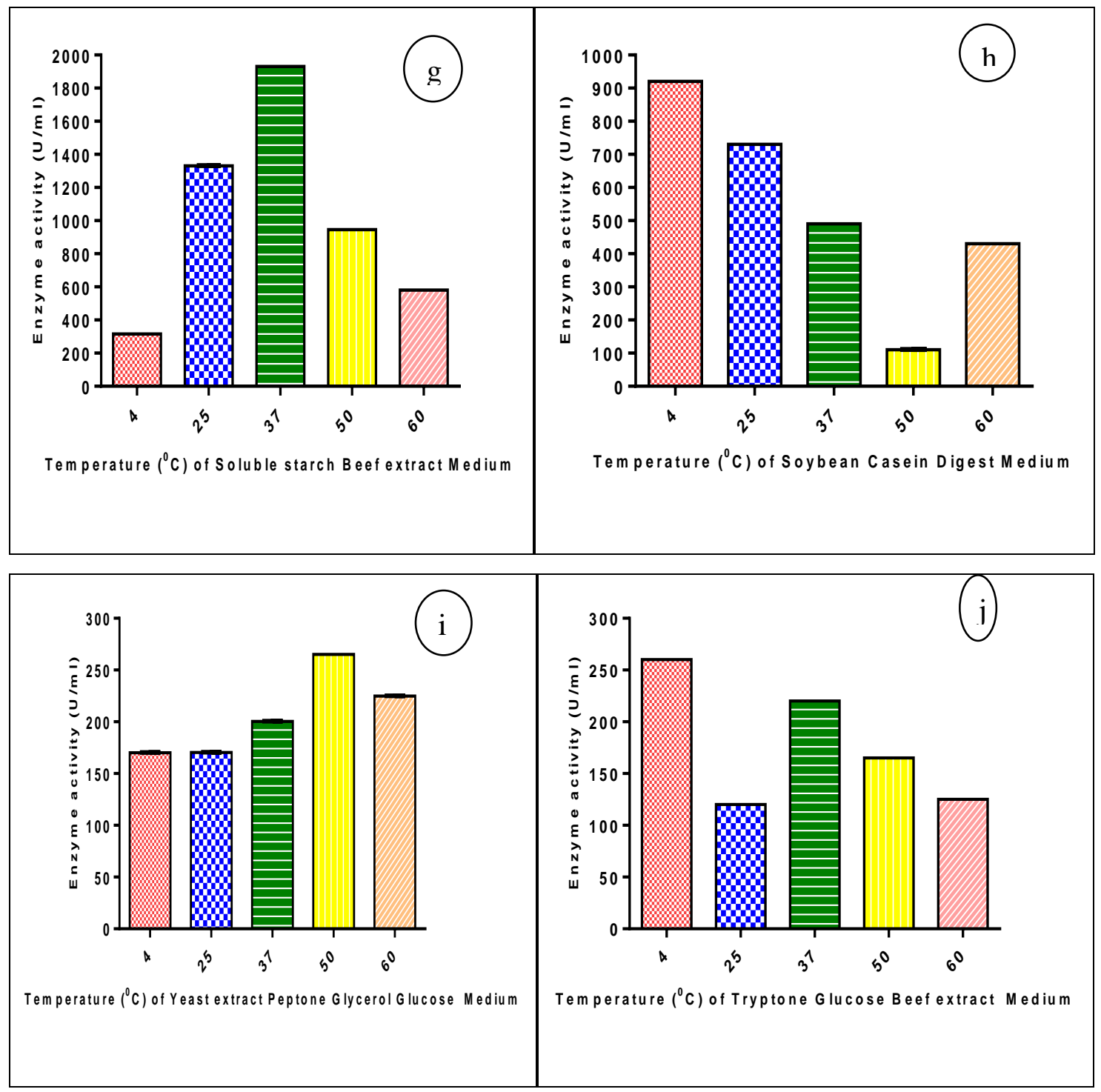

Table.1 The Range of Amylase Activity at Various Temperatures with Different Media

\begin{tabular}{|l|l|}
\hline Media & Amylase activity Range in U/ml \\
\hline Nutrient Broth (NB) & $80-280$ \\
\hline Luria Bertain Broth (LB) & $160-250$ \\
\hline Clarks and Lub Medium (CL) & $940-2560$ \\
\hline Pikovskaya's Medium (PK) & $1280-3380$ \\
\hline Tendler's Non-synthetic Medium (TNS) & $310-770$ \\
\hline Amylase Production Medium (APM) & $200-590$ \\
\hline Soluble Starch Beef Extract Medium (SB) & $315-1940$ \\
\hline Soybean Casein Digest Medium (SCD) & $10-930$ \\
\hline Yeast Extract peptone Dextrose Glucose Medium (YPDG) & $170-270$ \\
\hline Tryptone Glucose Beef Extract (TGB) Medium & $120-270$ \\
\hline
\end{tabular}


Nevertheless, the production was highest $(3371 \pm 0.50 \mathrm{U} / \mathrm{ml})$ in Pikovskaya's medium at $37^{\circ} \mathrm{C}$. The literature reviewed the amylase production in different media in psychrophilic condition $\left(4^{\circ} \mathrm{C}\right)$ in Alteromonas haloplanktis ${ }^{16}$, Nocardiopsis sp. 7326 (Groudieva et al., 2004) and Arthrobacter psychrolactophilus (Declerck et al., 2003). The zenith amylase production of mesophilic Bacillus species $\left(30^{\circ} \mathrm{C}-45^{\circ} \mathrm{C}\right)$ was communicated (Nagarajan et al., 2010; Pushpendra Singh et al., 2012; Francisco Fábio Cavalcante Barros et al., 2013; Hanumanthu Prasanna Lakshmi et al., 2013). Peak production of amylase in Bacillus species in thermophilic condition $\left(50^{\circ} \mathrm{C}-100^{\circ} \mathrm{C}\right.$ ) was documented (Sodhi et al., 2005; Schwab et al., 2009). Isolation of $\alpha$ amylase producing bacteria from the coastal waters of Bay of Bengal, Visakhapatnam (Suribabu et al., 2015). The optimization of physical parameters, carbon, nitrogen, mineral sources parameters of alpha amylase producing Brevibacillus borostelensis R1 (Suribabu et al., 2014).

In conclusion, the present studies were carried out to optimize the $\alpha$-amylase production of Brevibacillus borstelensis R1 using ten different media at various temperatures $\left(4^{0} \mathrm{C}, 25^{\circ} \mathrm{C}, 37^{\circ} \mathrm{C}, 50^{\circ} \mathrm{C}\right.$ and $60^{\circ} \mathrm{C}$ ) with constant $\mathrm{pH}$ 7.0. Among ten media taken, Pikovskays's medium proved to be optimal $\alpha$-amylase production medium for Brevibacillus borostelensis R1 at physical parameters of $\mathrm{pH} 7.0$, and at $37^{\circ} \mathrm{C}$. The optimum production of $\alpha$-amylase by submerged fermentation $(\mathrm{SmF})$ was observed at $37^{\circ} \mathrm{C}$ in Pikovskaya's Medium $(3371 \pm 0.50 \mathrm{U} / \mathrm{ml})$ and at $4^{0} \mathrm{C}$ in Clarks and Lub Medium (2551 $\pm 1 \mathrm{U} / \mathrm{ml})$.

\section{Acknowledgement}

We thank Management of Dr.Lankapalli Bullayya College, Visakhapatnam for the financial support and facilities provided to make this work possible.

\section{References}

Abha Singh, Chander Prabha, Vijayalakshmi and Sushma Kumari. 2012. $\alpha$ Amylase Assay of Bacillus Subtilis KC3: Isolated from Euphorbia Hirta Rhizosphere. International Conference on Biological and Life Sciences. 40: 12-16.

Akcan, N. Serin, B. and Uyar, F. 2012. Production and Optimization Parameters of Amylasesfrom Bacillus subtilis RSKK96 under Solid State Fermentation. Chem. Biochem. Eng. Q. 26:233-239.

Amoozegar, M.A. Malekzadeh, F. and Malik, K.A. 2003. Production of amylase by newly isolated moderate halophile, Halobacillus sp. Strain MA-2. J. Microbio. Meth. 52:353359.

Asoodeh, A. Chamani, J. and Lagzian, M. 2010.A novel thermostable, acidophilic alpha-amylase from a new thermophilic Bacillus sp. Ferdowsicous isolated from Ferdows hot mineral spring in Iran: Purification and biochemical characterization. Int. J. Biol. Macromol. 46:289-297.

Burhan, A. Nisa, U. Gökhan, C. Ömer, C. Ashabil, A. and Osman, G. 2003. Enzymatic properties of a novel thermostable, thermophilic, alkaline and chelator resistant amylase from an alkaliphilic Bacillus sp. isolate ANT-6. Proc. Biochem. 38: 13971403.

Declerck, N. Machius, M. Joyet, P. Wiegand, G. Huber, R. Gaillardin, C. 2003. Hyperthermostabilization of Bacillus licheniformis alpha-amylase and modulation of its stability over a 
50 degrees $\mathrm{C}$ temperature range. Protein Eng. 16: 287-293.

Feller, G. Bussy, O.L. Gerday, C. 1998. Expression of psychrophilic genes in mesophilic hosts; Assessment of the folding state of a recombinant $\alpha$ amylase. Appl. Environ. Microbiol. 64: 1163-1165.

Feller, G. Amico, D. and Gerday, C. 1999. Thermodynamic stability of a coldactive alpha-amylase from the Antarctic bacterium Alteromonas haloplanctis. Biochemistry 38: 4613 4619.

Francisco Fábio Cavalcante Barros, Ana Paula Resende Simiqueli, Cristiano José de Andrade, and Gláucia Maria Pastore. 2013. Production of Enzymes from Agroindustrial Wastes by Biosurfactant-Producing Strains of Bacillus subtilis. Biotechnology Research International 1:1- 9.

Groudieva, T. Kambourova, M. Yusef, H. Royter, M. Grote, R. Trinks, H. and Antranikian, G. 2004. Diversity and coldactive hydrolytic enzymes of culturable bacteria associated with Arctic sea ice, Spitzbergen. Extremophiles. 8: 475-488.

Hanumanthu Prasanna Lakshmi, Uppu Venkateswara Prasad, Sthanikam Yeswanth, VimjamSwarupa1, Osuru Hari Prasad, Mangamoori Lakshmi Narasu, Potukuchi Venkata Gurunadha Krishna Sarma. 2013. Molecular characterization of $\alpha$ amylase from Staphylococcus aureus. Bioinformation at the interface of physical and biological sciences. 9: 281-285.

Kuddus, M. Roohi, Saima, and Ahmad, I.Z. 2012. Cold-active extracellular aamylase production from novel bacteria Microbacterium foliorum GA2 and Bacillus cereus GA6 isolated from Gangotri glacier, Western Himalaya, Journal of Genetic Engineering and Biotechnology. 10: 151-159.

Michael, R. Smith, A.E. and James, C. Zahnley. 2005. Production of amylase by Arthrobacter psychrolactophilus. J. Ind. Microbiol. Biotechnol. 32: 277-283.

Miller, G.L. 1959. Use of Dinitro salicylic acid reagent for determination of reducing sugar. Analy. Chem. 31: $426-429$.

Mukherjee, A.K. Borah, M. Raí, S.K. 2009. To study the influence of different components of fermentable substrates on induction of extracellular $\alpha$-amylase synthesis by Bacillus subtilis DM-03 in solid state fermentation and exploration of feasibility for inclusion of $\alpha$ amylase in laundry detergent formulations. Biochem. Eng. J. 43: 149-156.

Nagarajan, M. Deborah Paripuranam, T. and Umamaheswari, S. 2010. Efficient production of Alpha-amylase from agro residues using Bacillus subtilis. J. Chem. Pharm. Res. 2: 442-448.

Pushpendra Singh, Paras Gupta, Ravindra Singh, and Rajesh Sharma. 2012. Factors affecting alfa Amylase Production on Submerged Fermentation by Bacillus sp. Int. J. of Pharm. \& Life Sci.. 3: 2243-2246.

Rajagopalan, G. and Krishnan, C. 2008. Alpha-amylase production from catabolite derepressed Bacillus subtilis KCC103 utilizing sugarcane bagasse hydrolysate. Bioresour. Technol. 99: 3044-3050.

Sailas Benjamin, R.B. Smitha, V.N. Jisha, S. Pradeep, S. Sajith, S. Sreedevi, Prakasan Priji, Unni, K.N. Sarath, Josh, M.K. 2013. A monograph on amylases from Bacillus spp. 
Advances in Bioscience and Biotechnology. 4: 227-241.

Schwab, K. Bader, J. Brokamp, C. Popovic, M.K. Bajpai, R. and Berovic, M. 2009. Dual feeding strategy for the production of alpha-amylase by Bacillus caldolyticus using complex media. N Biotechnol. 26: 68-74.

Siddiqui, Z.S. Shaukat, S.S. and Zaman, A.U. 2006. Alleviation of salinityinduced dormancy by growth regulators in wheat seeds. Turk. $J$. of Bot. 30: 321-330.

Sodhi, H.K. Sharma, K. Gupta, J.K. and Soni, S.K. 2005. Production of a thermostable $\alpha$-amylase from Bacillus sp. PS-7 by solid state fermentation and its synergistic use in the hydrolysis of malt starch for alcohol production. Proc. Biochem. 40: 525-534.

Suribabu, K. Lalitha Govardhan, T. and Hemalatha, $\quad$ K.P.J. 2014. Optimization of physical parameters of alpha amylase producing Brevibacillus borostelensis $\mathrm{R} 1$ in submerged fermentation. Int.jr. of Res. Eng. and Tech. 1(03): 517-525.

Suribabu, K. Lalitha Govardhan, T. and Hemalatha, K.P.J. 2014. Influence of carbon sources on $\alpha$-amylase production by Brevibacillus sp. under submerged Fermentation. Inter. jr. of research in eng. and tech. 03 (02):292-299.

Suribabu, K. Lalitha Govardhan, T. and Hemalatha, K.P.J. 2014. Optimization of various Nitrogen sources for the production of $\alpha-$ Amylase using Brevibacillus borstelensis $\mathrm{R} 1$ by Submerged fermentation.Int.J.Curr.Microbiol.Ap p.Sci. 3(4): 791-800.

Suribabu, K. and Hemalatha, K.P.J. 2014. International Journal of Engineering Sciences \& Research. Optimization of Mineral sources on $\alpha$-amylase production by Brevibacillus borstelensis R1 in Submerged Fermentation. 3(7): 926-934.

Suribabu, K. Lalitha Govardhan, T. and Hemalatha, K.P.J. 2015. Isolation of $\alpha$-amylase producing bacteria from the coastal waters of Bay of Bengal, Visakhapatnam. Indian Journal of Geo-Marine Science. 44 (5):1-4.

Teodoro, C.E.D. and Martin, M.L.L. 2000. Culture conditions for the production of thermostable amylase by Bacillus sp., Braz. J. of Microbio. 31: 298302.

Van der Maarel, M.J.E.C. Van der Veen, B. Utdehaag, J.C.M. Leenhuis, H. and Dijkhuizen, L. 2002. Properties and applications of starch converting enzymes of the alpha amylase family. J. Biotechnol. 94: 137-155.

\section{How to cite this article:}

Suribabu, K., and Hemalatha, K.P.J. 2016. Thermal Optimization of $\alpha$-amylase Production in Brevibacillus sp. Int.J.Curr.Microbiol.App.Sci. 5(3): 909-916. doi: http://dx.doi.org/10.20546/ijcmas.2016.503.105 